\title{
THE IMPACT OF LOCAL GOVERNMENT INVESTMENT ON CORPORATE DECISIONS ${ }^{14}$ Part 1
}

\author{
Puntillo Pina $^{15}$, Tenuta Paolo ${ }^{16}$
}

This work aims to provide evidence on the impact of public investment on local business decisions. In particular we want to see the effect of public investment on the development of local area - measured by GDP and employment - and therefore the effect that the development of the area determines the location decisions of businesses.

In other words, we therefore wish to demonstrate how the infrastructure is one of the determinants of competitiveness and development potential of an area of active firms. A good level of infrastructure produces significant advantages (so-called positive externalities) for the local economy because, not only allows to increase the productivity of factors of production, reducing costs, but also influences the degree of attraction of the area (residents, tourists, businesses, funders), the location decisions of new businesses, the strengthening of existing ones.

The conceptual framework draws on the contributions made by many national and international literature on the role that public investment play in economic growth in the territories and the attractiveness of the territory.

The paper is organized in two parts. Part 1 discusses the concept of local public investment, which is under a legal entity, examines the issue of investment planning and illustrates how the literature has suggested and tested empirically with reference to the role of public investment in the dynamics of growth and competitiveness of the territories. In the Part 2, is empirically tested the research hypothesis, through an econometric analysis, describing the models and variables used in the application of panel techniques, and presents the results of the estimates, while last section concludes with summary of some considerations.

\section{JEL: $G 380$}

Keywords: public investment, government, corporate decisions, policy making, local business decisions, development

\section{Introduction}

Italian local authorities are more than a decade at the center of an extensive reform process that has profoundly changed the conditions of operation, the reference is the so-called process of "decentralization" which involved, among other things, not only Italy but other countries [Hankla C., Downs W., 2010]. In applying the principles of subsidiarity, not only administrative functions, but even those of a planning are the responsibility of lower levels of government. Is attributed to local authorities, therefore, the responsibility to plan for investments in the territory. [Farneti F., 1998].

Together with the process of administrative federalism, is being implemented also the process of fiscal federalism, and the resulting shift from a centralized system of public finance to public finance system independent. In this context, the strategic viability of local plays a crucial role in promoting economic development in the area [Smith B., 2008].

In light of this premise, the present work aims to provide evidence on the impact of public

\footnotetext{
${ }^{14}$ This paper is the result of shared thoughts of the authors. However, when drafting, the paragraphs $1,5,6$ are to be attributed to Pina Puntillo and the paragraphs 2, 3, 4 are to be attributed to Paolo Tenuta.

${ }^{15}$ Researcher in Business Economics University of Calabria Department of business science.

${ }^{16}$ Research Fellow in Business Economics University of Calabria Department of business science.
} 
investment decisions have on local business. In particular we want to see the effect of public investment on the development of local area - measured by GDP and employment - and therefore the effect that the development of the area determines the location decisions of businesses.

It will illustrate the economic theory to support research that would lead, I will explain the concepts of current expenditure and capital expenditure, and after specifying the differences, not only in terminology, between investment spending and capital spending, will be analyzed management aspects, accounting and financial investment decisions by local authorities. It will then detail the importance, in terms of policy, for careful planning and prior assessment of the investment. Finally, the main effort was put into empirical research and analysis of results that have resulted.

The provision of infrastructure is therefore one of the determinants of competitiveness and development potential of an area of active firms. A good supply of infrastructure in fact have positive externalities ${ }^{17}$ for the local economy, increasing the productivity of factors of production and reducing costs. Moreover, the presence of good service quality influences the degree of attraction of the area (residents, tourists, businesses, donors): the infrastructure is therefore crucial for the location of new businesses, strengthening existing ones and the attractiveness of the territories.

In light of the interest that these studies raise the scientific community, and given the current and practical implications on local economic systems (we refer to the forecasts of the central government to reduce transfers to local authorities) the quantitative analysis focuses directly on capacity of local public expenditure for investments "to determine" the economic growth of regions.

In other words, the econometric analysis aims to demonstrate that the main local public investment "determine", "influence" the levels of development of territories.

The main assumption is that you want to verify that an increase in investment spending increases the wealth of the territories. Moreover, whereas in recent years has been adopted the political strategy of using the civil service employment as a driver, it is believed that employees of public institutions has absorbed most of the available financial resources that could instead be devoted to investment and that could favor economic development, so it is assumed that staff costs have a negative impact on growth of the area and therefore on the location decisions of businesses.

If you look at the budgets of public administrations, in fact, the amount allocated for current expenditure always exceeds that of capital expenditure, in other words, public authorities allocate financial resources to pay the costs of mandatory (including almost all the costs current), to the detriment of those discretionary which are precisely the costs of investment.

It is therefore considered that if the investment costs are a driving force of economic development, because they are "held back", "bound" by the staff costs, then the public sector is a major constraint to local development in the light of this argument it is assumed that staff costs negatively determine the levels of development.

Through a multivariate linear regression model estimated by OLS using panel data techniques the research hypotheses that we want to prove are the following:

Hypothesis H1: the increase of the surface, increases the level of regional development.

Hypothesis H2: the increase of investment spending, raise the level of regional development.

Hypothesis H3: the increase of personnel expenses, decreases the level of regional development.

Hypothesis H4: in Center North geographical macro-area shows a higher level of development, thus determining the location of the joint development of the territory.

\section{Public expenditure in the laws of accounting and accounting theory}

The term "public expenditure" means the disbursement of economic assets by the state and other public bodies to produce goods and services to meet the needs of the community. [Farneti F.,

\footnotetext{
${ }^{17}$ The positive externalities consist in a particular activity produces benefits in the hands of other parties not directly involved in that activity.
} 
1998].

In our financial system, the payment of any expenditure should be a substantive law that is the source of legal expenses, as well as a special appropriation in the budget that has as a necessary tool for the material implementation of the substantive law imposing an obligation or entitles it to make the same expenditure [Buscema S., 1971].

Public expenditure can be distinguished by different criteria and the influence of such distinctions, of course, influences the allocation of the burden.

Among the various classification criteria the distinction between current expenditure and capital expenditure is of particular importance. First, the mandatory financial statements for local governments, issued by DPR 194/1996, reproduce this categorization, representing, respectively, the Title I and Title II of Part I of the annual budget expenditure. Therefore the distinction between current expenditure and capital expenditure in terms of the notes first budget balances (whether partial or total). Moreover, it is particularly important in relation to hedging of financial needs generated by such fees: it is known that the first constitutional law in 2001 decided that the borrowing is permitted only to finance capital expenditure. It is, therefore, necessary to clarify what is meant by investment spending.

\section{Public spending for local investments. Accounting and financial aspects}

The issue of investment and, consequently, that of the related sources of funding has always been one of the most interesting aspects of the management of local resources, as will be detailed in paragraph 6 , and the effects directly and indirectly determine the relevant territory [D'Aristotile E., 2009]. Nevertheless, the legislature has long declined to provide a clear and full definition of the term "investment" [Puddu L., 2005].

Regarding Italian commercial law, in fact, the concept of "investment" has been fully defined only recently.

The legislature originally introduced the distinction between current expenditure and investment expenditure in 1964 with Law No 62, c.d. Curtis Law, in place of the distinction between ordinary expenses and extraordinary expenses, simply define the cost of investment (or capital account) as those expenses related to direct investments and indirect, as well as in operations for granting loans. The same position was adopted by the legislature in 1979 when the accounting reform of Local Government of the DPR No 421. Even the Legislative Decree No 267 of 2000 provides a precise definition of the criteria necessary to distinguish from those in current expenditure and capital investment by the latter.

It was not until 2001 that the Constitutional Court began to initiate a process of clarifying the concept of local public investment.

The exact definition of investment expenditure is relevant when the financing of this expenditure does not provide you with the ordinary means, having put the constitutional law No. 3/2001 (reform of Title V of the Constitution) an absolute prohibition on borrowing for purposes other than investment.

In particular, the new art. 119, paragraph 6 of the Constitution to provide for municipalities, provinces, metropolitan cities and regions the opportunity to borrow only to fund "investment expenditure".

However, while identifying the cost of investment as the only type of expenditure for which shall be no borrowing from local government, the legislature does not dwell on their exact specification.

Consequently, just as a result of the ban on borrowing costs for non-investment posed by constitutional law No. 3/2001, was now the subject of debate the exact definition of "investment expenditure."

The Legislature returned to the issue with two further initiatives:

1) The Finance Law 2003 which introduced a penalty system that provides for the nullity of the acts and agreements adopted in violation of Art. $1196^{\circ} \mathrm{c}$. Constitution, and the possibility of 
the Court of Auditors to impose a financial penalty to the administrators who take the relevant decision;

2) The Finance Law 2004 (Law No. 350/2003) which was due to give practical effect to the prohibition of borrowing for investment expenditure, providing for the first time a complete definition of "debt" and "investment". This law is an important step because it sheds light on a topic of discussion among theorists and operators of the sector in recent years.

In the legislature, in particular, art. 3 of FL 2004, paragraphs 16 to 21, listed the types of debt eligible for the purposes of Article 119, paragraph 6 of the Constitution and listed the items of expenditure to be considered investments for the same purposes.

The list of types of investment and debt was previously subject to change by decree of the Ministry of Economy and Finance, after Istat: this is available to paragraph 17, fourth period, and paragraph 20, art. 3 of the Finance Law 2004; these paragraphs, however, were later declared unconstitutional by the Constitutional Court ruling No. 425/2004.

The opinion expressed by the sentence no $425 / 2004$ originated is found in art. 3, paragraphs 16 to 21 of Law No 350/2003 by certain provinces and regions [Barbero M., 2005], the Court declared the legitimate contested paragraphs, with the exception of Section 17, last sentence, and 20, which give the Minister of Economy and Finance after hearing the ISTAT, the power to have a decree with modifications to the types of "debt" and "investment" for the purposes set out in Article. 119 , sixth paragraph of the Constitution.

Beyond the judgments of constitutionality it is important to remember that the sentence in question has, however, strengthened the prohibition on borrowing for investment expenditure for the smaller local authorities (with the exclusion, then, the central government) already placed with the law Constitution of 2001.

\section{The distinction between investment expenditure and capital expenditure}

In the light of legislative changes on local authority borrowing for investment expenditure it is useful to make a careful examination of the classification of capital expenditure and investment.

It is wrong to think that capital expenditure and investment are identical. When it comes to investment in the local budget means essentially public works, as defined by art. 2 of Law 109/1994: "Activities of construction, demolition, restoration, renovation and maintenance of services and facilities ..." and their acquisition and sale, exchange, maintenance, renovation [Marotta G., 2004].

The concept of capital expenditure instead assumes a broader meaning. It includes, in addition to investment costs (over the cost of public works), but all other expenses and deferred expenses that increase the fixed assets of the entity, such as purchases of motor vehicles, equipment, investments, contributions, capital transfers and in general all the costs that constitute two essential criteria [ODCEC Ivrea, Pinerolo and Turin, 2008]:

1) the recurrence,

2) the object of expenditure and its place in the budget.

The first criterion is generally used to distinguish in the current account balance from the capital. The definition of capital expenditure actually derives from the definition of current expenditure which is characterized by normal conditions [Circular of the Ministry of the Interior No 11/1978]: capital expenditures are therefore in the nature of extraordinary expenses ie those that do not occur with a high degree of regularity and continuity.

The second criterion refers instead to the nature of expenditure on the basis of the following "interventions" allocated to Title II, which are identified by the DPR 194/1996:

01 acquisition of real estate

02 onerous expropriation and services

03 purchases of specific achievement in economics

04 use of third party assets for achievements in economy

05 acquisitions chattels, machinery and technical scientific equipment 
06 external professional contracts

07 capital transfers

08 shares

09 injections

10 concessions of credits and advances

These items constitute the then capital spending, broader category than the investment costs, according to the doctrine for a proper allocation of an event management including the cost of investment is necessary to determine, for each intervention of Title II capital expenditures, if you take charge of the characteristics of "investment" [Baldi L., 2005].

Spending takes on the characteristic of investment expenditure if it is on all the assets, tangible and intangible-owned repeated participating for several years paid and productive processes of local authorities and that, as such, are shown as the balance sheet [Di Massa P., 1989; D'Aries C., D'Atri A., Mazzara L., 1998], and also participate in the determination of income for the year with their depreciation. In other words it can be assumed that the 'investment expenditure' are all those incurred by local authorities for construction and/or acquisition of property, not for normal consumption and, therefore, are permanent facilities available to local communities, which would increase the assets [Falcone G., 1998; D'Aristotile E., 2000].

This will come to the conclusion that the cost "investment" are a subset of capital expenditure are characterized by these fundamental elements just mentioned.

Among the measures of expenditure of Title II, the ones that no transactions can not give rise to an investment are transfers of capital and credit allocation.

The first recorded disbursements to institutions with a special agencies, companies and households in the form of grants, allocations, subsidies characterized by the absence of a countervailing obligation on the recipient and the purpose for which they are granted (or construction works Repeated acquisition of property in fertility). However, if capital transfers are provided for the benefit of persons belonging to public administrations, they are considered investments.

The second, however, collect the payments in favor of special and associates and subsidiaries for operations in support of cash imbalances which occurred during the year, the same intervention as to include those "movements of funds" for the transfer of funds out of cash only. Again we cannot talk because the logic of investment income and balance sheet amounts reported in the intervention and then paid for the shares are paid credits [D'Aristotile E., 2004].

It can be argued therefore that the distinction between investment and expenditure in capital account is limited to transfers of capital to private entities not included within the government sector, and granting of loans and advances. These two cases are capital expenditures but investments financed through debt, all other cases of investments are properly capital expenditures.

\section{Investment planning in a logic of policy}

The implementation of public investment that generates revenue and expenses is reflected in the annual budgets of local government as a result of the physical, economic and environmental aspects related to the location of infrastructure.

The choice of investments, the responsibility of policy makers, must be based on two types of analysis, one on historical data and the other on prospective data. The first will establish the status quo before the investment: the financial and fiscal health, any leeway in the budget concerning government infrastructure, the stock of heritage buildings (residential, industrial, commercial) and the estimates of urban development, the level of public services offered, and the main difficulties to cope with the effects caused by the infrastructure (increased needs of the area), the second will simulate the projection of the main items of income and expenditure based on assumptions on the effects on the administration in an appropriate timeframe. In particular, we should check whether the entity will incur additional costs in the future or the need for new investment in urban development and its financial capacity to fulfill them [Morese F., 1982]. 
In addition, the financial analysis should consider the time dimension. The temporal dimension concerns the timing of payments. The determination of the time horizon should be made on the basis of the timing of the effects induced by the infrastructure, divided into three phases:

1) the stages prior to implementation;

2) the lifetime of the infrastructure;

3) an initial period of operation in which they begin to manifest the territorial changes brought about by the infrastructure, modification of urban development, location of new industrial facilities etc..

From a macroeconomic perspective, the choices inherent in large infrastructure projects have to meet strategic logic multi-level (regional interests, national and EU) and require the sharing of information between stakeholders and their involvement in the construction of consensus. From a business point of view but their implementation requires, in addition to the evaluation of design alternatives, a careful evaluation of policies for financing the work. The investment choices are in fact a decisive influence on economic and financial balance of future budgets of the institution [Giacomelli P., 1998].

A body or board was thus set up to approve the business plan, which is a legal requirement for the resolutions approving the execution of investment projects and for decision-taking on mortgages [Article 200 Tuel]. The business plan must be drawn to determine the price for the service are able to ensure balance both economic and financial investment. An investment is characterized by economic equilibrium when, in the time chosen for its assessment, the discounted stream of revenues from the investment is at least sufficient to cover the amount of discounted costs, including depreciation charges technically and financially.

An investment is characterized by financial stability when, in the period chosen it is able to produce, for each financial year, a volume of financial resources that can help you meet the amount of cash outlay for the reimbursement of the funds received and management of 'invested in the

The overall assessment of a proposed investment therefore requires:

1. Analysis of user needs which fall on the technical and economic feasibility of various financial and investment alternatives. The choice will fall on that project whose benefits outweigh the costs incurred;

2. Analysis of capital expenditure inclusive of VAT, the period in respect of which express an opinion of convenience, financial charges and capital repayments in relation to the choice of financing, management and financial burdens on indirect entity's financial statements, once the investment, and any major or minor resources for the benefit and / or the budget itself;

3. The timetable for the drafting of the final and executive projects, procurement of funding sources, and the procedures for the identification and choice of partner, foster care and the start of work and closure of work and testing;

4. Time to feature the work, and / or system.

\section{The role of public investment in the dynamics of growth and competitiveness of the territories}

The empirical economic literature to support the axiom that the allocation of public works, infrastructure, physical capital and in general public, is a positive factor for the development and competitiveness of regional economies is significant, both nationally and internationally. Are numerous and related to various land areas that are empirical work support the idea that the growth of capital generated by public spending on infrastructure to provide a positive and significant contribution (although greater or lesser extent depending on the circumstances) to productivity local private sector [Atukeren E., 2005], and to output growth and production [Romp W., De Haan J., 2007; Sanchez-Robles B., 2007].

This seems to have happened in the U.S. during the 70s and 80s of last century [Eberts, 1986; Eberts, 1990], in regions and large areas Metropolitan Germany and France [Aubert and Stephan, 2000; Kemmerling and Stephan, 2002] and in the Spanish [Boscà et al., 2001]. 
In fact from the thirties, the economic literature array Keynesian had sealed the importance of investment in infrastructure for their ability to trigger a multiplier effect on the demand side and create the preconditions for the growth of a country [Tondini E., 2008]. In particular, Keynesian models predict that in the short term infrastructure spending has a positive impact on GDP and employment and spending that very purpose is to support employment in the early stages of adverse cyclical, passing the long-term capital investments provide a public positive contribution to GDP thanks to the stimulus given to investment in private capital, public and private capital would therefore be complementary (crowding in) and not substitutes. [Di Giacinto V., Micucci, G. Montanaro P., 2009].

On the issue of the macroeconomic impact of infrastructure is important to remember the empirical literature of Aschauer: in his studies on the productivity of public capital for the U.S. [1989a; 1989b], he introduced an aggregate production function approach with static single equation, in which the public capital was treated the same as the input of labor and private capital. The author was a large positive effect of public capital on U.S. GDP, suggesting that public investment would be self-financing through higher tax revenue.

A large empirical literature has taken the building on the work of Aschauer and some authors [Baxter and King, 1993] have explored the complex channels through which public capital exerts its effects on the wealth produced in a general equilibrium framework: directly, because the investment in infrastructure is part of GDP, indirectly, as the public capital can influence the level of other inputs, such as employment and private capital.

Also with regard to Italy, Fabiani and Pellegrini [1997] show that in addition to training and geographical location, infrastructure spending has been a determining factor for economic growth both for the convergence of the Italian provinces during the period 1952-1992.

In light of the above and supported by the different economic theories can therefore be said that public investment in infrastructure have a significant impact on GDP, employment and overall economic growth in the territories. At local level the implementation of the investment produces widespread benefits: in general increases the competitive differentiation of the territories and thus the degree of attractiveness of those relying on the effects of Keynesian type.

In particular the provision of local public investment on the one hand affects the economic, social, environmental (changes in residential property settlement and productive system of mobility, environmental framework, labor markets and real estate, increase/decrease of population) and secondly generates growth in demand for and supply of public services caused by changes in infrastructure and changes the tax and local government involved [Barman TR, Gupta MR, 2010].

Essentially, therefore, the infrastructure is one of the determinants of competitiveness and development potential of an area of active firms: the presence of infrastructure of good quality affects the level of development and consequently on the location of new businesses the reinforcement of existing ones and the degree of attractiveness of the territories.

It is necessary and proper to make a further clarification and to dwell on another aspect: the role of adequate infrastructural facilities is crucial not only economic growth but also in reducing regional imbalances.

The reasons given to support a policy of expansion of infrastructure facilities are in fact generally focus on the objective of creating conditions that promote growth, expansion and efficiency of the economy, on the one hand, and the reduction of inequalities and achieving greater economic and social cohesion, on the other [Di Palma M., Mazziotta C., 2003].

An extensive analysis of literature has attempted to interpret the economic and territorial disparities and to develop policies and actions to create conditions for achieving a substantial economic and territorial cohesion among countries and between regions within each country. Theories of the fifties and sixties, with the important work of Hirschmann [1958], Perloff [1963], Hansen [1965], followed in subsequent years based on significant contributions empiricalquantitative analysis, including remember those Biehl [1986] and more recent ones of Barro [1991], Barro and Sala-i-Martin [1992], Costa-Font J., Rodriguez-Oreggia E., [2005] and Giuranno MG [2009]. 
All these authors essentially argue a theory of skiing: the infrastructure plays a significant role (along with other variables, of course) when determining a growth process more pronounced in the lagging regions, such as to reduce the existing regional disparities and enable the start of a process of convergence of regional economies with different levels of development.

Own public investment can be the engine of economic and social development, to activate the lever to overcome or at least reduce the territorial duality of our country. Italy is one of the countries where it persists a long time the territorial divide between North and South.

He even notes that the Italian case is the only example of a country where internal differences have never been significantly reduced: between 1955 and 2005, unlike what happened in all other nations, the Italian regions lagging in development have not been able to show growth rates significantly above the national average [Iuzzolino G., 2009].

Ultimately, the Italian economic dualism, which sees a significant proportion of the population reside in a very poor than the national average, is far more serious than other countries with similar levels of development and approaches, however, to an uneven playing field that characterize the less economically advanced countries.

Spatial inequalities in Italy are of a structural nature. The internal disparities of income now appear significantly higher than all nations in comparison with levels of development comparable to ours. That is to say that the question of southern Italy is placed on dimensions of particular gravity, not only in the economic history of our country, but also by international standards.

For the purposes of comparison, it is significant to consider the case of Germany, another country with strong traits of territorial dualism.

It is to be noted that the government action of Germany in the years after reunification (October 3, 1990) was characterized by tenacity and consistency in the point towards the goal of recovery of the gap between the two parts of the country in terms of production, infrastructure and Wellness, a non-negligible costs.

PROBLEMS: While recognizing the considerable efforts made in an attempt to restore the eastern Länder in the united Germany, but you can not hide the fact that the result has not yet been reached: the process of rapid growth in the first years after reunification was followed by a growth phase slow and insufficient to fill the gap with the western regions in a short time. However, it acknowledged the success of the policies offered to the public in having the reunification of the Eastern Länder an allocation of infrastructure level equivalent to that of the rest of the country, which has not yet happened in Southern Italy [Martinez Oliva JC, 2009].

The comparison between the German experience and our South, but with due caution related to the different historical and institutional conditions and different initial factor endowment, it is therefore instructive in that it allows to confirm the anomaly of the Italian dualism in the European market. The Italian dualism is presented in relation to productivity, income, employment and also with regard to public investment: in particular, in Italy there is a gap in infrastructure is strong compared to other industrialized European countries, both within and between the South and the Center North.

The causes underlying these differences are many and not all be controlled at national level between the various causes is important to remember above all the need to contain public spending that occurs every year more and more relentless with the Pact of Stability and Budget Laws. Also at European level, the analysis shows that the level of public investment has been determined in recent years by income taxation policies and particularly the need to contain expenditure and the budget appropriations, which were found to be higher than for current expenditure expenditure in capital account [Agenor P.-R., 2009; Mehrotra A., Valila T., 2006].

Different analysis, among others, have shown that the expenditure in capital account are positively and significantly correlated with economic growth, unlike the current expenses [Bose N., Haque ME, Osborn DR, 2007].

In this context, it is interesting to investigate the determinants of land development in order to understand based on the assumptions made and the search through the construction of an econometric model, what kind of spending most conducive to economic growth: in other words, if 
are true hypothesis under which the cost of investments encourage the development costs for staff and hinder the growth of the territories.

\section{References}

1. Agenòr, P.-R. (2009), Infrastructure Investment and Maintenance Expenditure: Optimal Allocation Rules in a Growing Economy, Journal of Public economic Theory, 11(2) (2009) 233-250.

2. Aschauer, D. (1989a), Is Public Expenditure Productive?, Journal of Monetary Economics, 23 (1989a) 177-200.

3. Aschauer, D. (1989b), Does Public Capital Crowd Out Private Capital?, Journal of Monetary Economics, 24 (1989b) 171-188.

4. Atukuren, E. (2005), Interactions Between Public and Private Investment: Evidence from Developing Countries, Kyklos, 58(3) (2005) 307-330.

5. Aubert, S., Stephan, A. (2000), Regionale Infrastruktur Politik und ihre Auswirkung auf die Produktivität: ein Vergleich von Deutschland und Frankreich, Berlin: Wissenschaftszentrum, (2000).

6. Baldi, L. (2005), Investimenti: le disposizioni della finanziaria 2005 in materia di finanziamento, Azienditalia, 8 (2005) 509.

7. Baltagi, Badi, H. (2001), Econometric Analysis of Panel Data, Chichester: John Wiley \& Sons, (2001).

8. Barbero, M. (2005), Golden Rule: non è tutt'oro quel che luccica!, Le Regioni, 4 (2005) 675.

9. Barman, TR, Gupta, MR (2010), Public Expenditure. Environment and Economic Growth, Journal of Public economic Theory, 12(6) (2010) 1109-1134.

10. Barro, RJ (1991), Economic Growth in a Cross Section of Countries, The Quarterly Journal of Economics, 106(2) (1991) 407-443.

11. Barro, RJ, Sala-I-Martin, X. (1992), Convergence, The Journal of Political Economy, 100(2) (1992) 223-251.

12. Baxter, M., King, RG (1993), Fiscal Policy in General Equilibrium, American Economic Review, 83(3) (1993) 315-333.

13. Biehl, D. (1986), The contribution of infrastructure to regional development: final report, Luxembourg: Office for Official Publications of the European Communities, (1986).

14. Bose, N., Haque, ME, Osborn, DR (2007), Public Expenditure and Economic Growth: a disaggregated Analisys for Developing Countries, The Manchester School, 75(5) (2007) 533-556.

15. Buscema, S. (1971), Il bilancio, 1, Milano: Giuffrè, (1971).

16. Costa-Font, J., Rodriguez-Oreggia, E. (2005), Trade and the Effect of Pubic Investment on Regional Inequalities in Heterogeneously Integrated Areas, The World Economy, 28(6) (2005) 873-891.

17. D’Aries, C., D’Atri, A., Mazzara, L. (1998), Enti locali - Il sistema informativo contabile, Milano: Ipsoa, (1998).

18. D’Aristotile, E. (2000), Gli investimenti negli enti locali: la programmazione, la valutazione, la contabilizzazione, la scelta della fonte di finanziamento, Gorle: Cel, (2000).

19. D'Aristotile, E. (2004), La nozione di investimento e indebitamento dopo la legge finanziaria 2004, Azienditalia, 5 (2004) 323.

20. D'Aristotile, E. (2009), La nozione di investimento e di indebitamento nelle disposizioni normative riguardanti gli enti locali, in Amatucci, F., Pezzani, F., Vecchi, V. (a cura di) (2009), Le scelte di finanziamento negli enti locali, Milano: Egea, (2009).

21. Di Giacinto, V., Micucci, G., Montanaro, P. (2009), Effetti macroeconomici del capitale pubblico: un'analisi su dati regionali, Mezzogiorno e politiche regionali, Banca d'Italia, 2 (2009) 279-317. 
22. Di Massa, P. (1989), Il finanziamento e la realizzazione delle opere pubbliche negli enti locali, Ceranesi: Maggi, (1989).

23. Di Palma, M., Mazziotta, C. (2003), Infrastrutture, competitività e sviluppo: il caso italiano, Economia Italiana, 3 (2003) 534.

24. Eberts, RW (1986), Estimating the contribution of urban public infrastructure to regional growth, Working Paper, URL: http://www.clevelandfed.org/research/Workpaper

25. Eberts, RW (1990), Public infrastructure and regional economic development, Economic Review, 90(Q1) (1990) 15-27.

26. Fabiani, S., Pellegrini, G. (1997), Education, infrastructure, geography and growth: an empirical analysis of the development of italian provinces, Temi di discussione, Roma: Banca d'Italia, 323 (1997).

27. Farneti, F. (1998), Gestione e Contabilità dell'ente locale, Santarcangelo di Romagna: Maggioli, (1998).

28. Falcone, G. (1998), Il finanziamento degli investimenti negli enti locali, Guida normativa, Gorle: Cel, (1998).

29. Giacomelli, P. (1998), Programmazione e finanziamento degli investimenti, Azienditalia, 5(3) (1998) 135-136.

30. Giuranno, MG (2009), Regional income Disparity and the Size of the public sector, Journal of Public economic Theory, 11(5) (2009) 667-873.

31. Hankla, C., Downs, W. (2010), Decentralisation. Governance and the Structure of Local Political Institutions: Lessons for Reform?, Local Government Studies, 36 (6) (2010) 759783.

32. Hansen, M. (1965), Unbalanced Growth and Regional Development, Western Economic Journal, 4 (1965) 3-14.

33. Hirschmann, OA (1958), The Strategy of Economic Development, London: Yale University Press, (1958).

34. Iuzzolino, G. (2009), I divari territoriali di sviluppo in Italia nel confronto internazionale, Mezzogiorno e politiche regionali, Banca d'Italia, 2 (2009) 428.

35. Kemmerling, A., Stephan, A. (2002), The Contribution of Local Public Infrastructure to Private Productivity and its Political Economy: Evidence from a Panel of Large German Cities, Public Choice, 113(3-4) (2002) 403-424.

36. Marotta, G. (2004), La definizione di spesa in conto capitale e di investimento dopo la legge finanziaria 2004, La Finanza Locale, 5 (2004) 42.

37. Martinez Oliva, JC (2009), Riunificazione intertedesca e politiche per la convergenza, Mezzogiorno e politiche regionali, Banca d'Italia, 2 (2009) 479-502.

38. Mehrotra, A., Valila, T. (2006), Public Investment in Europe: Evolution and determinants in perspective, Fiscal Studies, 27(4) (2006) 443-471.

39. Morese, F. (1982), Metodologia decisionale nella programmazione degli investimenti pubblici, Economia pubblica, 9 (1982) 395.

40. ODCEC di Ivrea, Pinerolo e Torino (2008), Il finanziamento degli investimenti negli enti locali, Corso di formazione in materia di enti locali, $\mathrm{VI}^{\wedge}$ giornata, URL: http://www.odc.torino.it/public/convegni/con15541.ppt

41. Perloff, HS (1963), How a region grows: area development in the U.S. economy, New York: Committee for economic development, (1963).

42. Romp, W., De Haan, J. (2007), Public Capital and Economic Growht: a Critical Survey, Perspektiven der Wirtschaftspolitik, 8(S1) (2007) 6-52.

43. Sanchez-Robles, B. (2007), Infrastructure Investment and Growth: some empirical evidence, Contemporary Economic Policy, 16(1) (2007) 98-108.

44. Smith, B. (2008), Good governance and development, Public Administration and Development, 28(3) (2008) 251.

45. Stock, JH., Watson, MW (2009), Introduzione all'Econometria, Milano: Pearson Education Italia, (2009). 
46. Tondini, E. (2008), Infrastrutture e sviluppo: un legame ancora da esplorare, AUR\&S, 11 (2008) 243. 